Ethiopian Journal of Environmental Studies \& Management 8(5): 530 - 540, 2015.

ISSN:1998-0507

doi: http://dx.doi.org/10.4314/ejesm.v8i5.6

Submitted: February 20, 2015

Accepted: June 25, 2015

\title{
ANALYSIS OF THE TEMPORAL EVOLUTION OF TOTAL COLUMN NITROGEN DIOXIDE AND OZONE OVER NAIROBI, KENYA USING DAILY OMI MEASUREMENTS
}

\author{
*MUTAI, B.K., ${ }^{1}$ MUTHAMA, J.N., ${ }^{1}$ NG'ANG'A, J.K. ${ }^{1}$ AND NGAINA, J.N. ${ }^{2}$ \\ ${ }^{1}$ Department of Meteorology, University of Nairobi, P. O. Box 30197-00100, Nairobi, Kenya \\ ${ }^{2}$ World Meteorological Organization, Regional Office for Eastern and Southern Africa, P.O. \\ Box 1395-00606, Nairobi, Kenya
}

\begin{abstract}
Concurrent measurement and analysis of Nitrogen dioxide $\left(\mathrm{NO}_{2}\right)$ and Ozone $\left(\mathrm{O}_{3}\right)$ are essential for improved understanding of ozone distribution. This study sought to analyse the temporal evolution of total column $\mathrm{NO}_{2}$ and $\mathrm{O}_{3}$ over Nairobi using satellite-derived daily data between 2009 and 2013. Seasonality is observed in $\mathrm{O}_{3}$ distribution with minimum and maximum occurring during the dry and wet seasons, respectively. Additionally, a lag of about a month or two occurs between the onset of a season and corresponding minimum or maximum $\mathrm{NO}_{2}$ and $\mathrm{O}_{3}$ concentration. The established association between monthly $\mathrm{NO}_{2}$ and $\mathrm{O}_{3}$ is such that, above average concentration of $\mathrm{NO}_{2}$ is likely to lead to above average levels of $\mathrm{O}_{3}$ during the same month $(r=0.79)$ and below average levels about 5 months later $(r=0.39)$. The Quasi Biennial Oscillation (QBO) is the main phenomenon behind the oscillating biennial feature exhibited by $\mathrm{NO}_{2}$ and $\mathrm{O}_{3}$ interannual trend. The study shows that $\mathrm{NO}_{2}$ and $\mathrm{O}_{3}$ are increasing at annual average rates of about $0.27 \%$ and $0.46 \%$ per year compared to mean values, respectively. Daily variation of both $\mathrm{NO}_{2}$ and $\mathrm{O}_{3}$ depicts stagnating trends over the entire period of study. This difference is attributed to the fact that, whereas daily $\mathrm{NO}_{2}$ and $\mathrm{O}_{3}$ are influenced by mechanisms that control the slow shift between the dry and wet periods within the course of a year, interannual variability is driven by the differences in each year's general weather conditions.
\end{abstract}

Key Words: Evolution, Nitrogen dioxide, Ozone, Total Column, Quasi Biennial Oscillation

\section{Introduction}

Ozone $\left(\mathrm{O}_{3}\right)$ and Nitrogen dioxide $\left(\mathrm{NO}_{2}\right)$ are very significant species in the Earth's atmospheric chemistry and have an influence on radiative forcing of the climate system (e.g., Herman, 2010). The atmospheric formation, dispersion, destruction, and transport of $\mathrm{O}_{3}$ are influenced by meteorology and photochemical mechanisms involving various species such as oxides of nitrogen (David and Nair, 2011). For this reason, simultaneous measurements and analysis of $\mathrm{O}_{3}$ and $\mathrm{NO}_{2}$ are, therefore, essential for improved understanding of ozone photochemistry and variation.

$\mathrm{NO}_{2}$ is produced primarily by combustion processes resulting from transportation, industry, and power plants (Seinfeld and Pandis, 2012). Over South Africa for example, Edward et al. (2003) were able to identify biomass burning and lightning as the two principal tropical sources of this important $\mathrm{O}_{3}$ precursor.

*Corresponding author: Mutai, B.K.

Email: berth@uonbi.ac.ke 
Reactive nitrogen compounds play a critical role in atmospheric chemistry, directly and indirectly controlling ozone production (Finlayson-Pitts and Pitts, 2000). Moreover, $\mathrm{NO}_{2}$ may also play a significant role in radiative forcing of the atmosphere (Solomon et al., 2007). Stratospheric $\mathrm{NO}_{2}$ shows a diurnal cycle with maximum concentrations around sunset and a seasonal cycle with maxima in summer and larger abundance at midlatitudes and high latitudes than in the tropics (Liley et al., 2000).

In the troposphere, nitrogen oxides significantly contribute to poor air quality (Celarier et al., 2008). At short-term concentrations exceeding $200 \mu \mathrm{g} / \mathrm{m}^{3}, \mathrm{NO}_{2}$ is a toxic gas which causes significant inflammation of the airways (WHO, 2006). Tropospheric $\mathrm{NO}_{2}$ depicts seasonal patterns showing winter maximum (Cede et al., 2006). Globally the distributions of tropospheric $\mathrm{NO}_{2}$ columns are lowest during summer, due to rapid loss by reaction with $\mathrm{OH}$ (Martin et al., 2003). At any given location, the diurnal variation is the result of a complex interaction between the emission source field, photochemical lifetimes, advection, and the levels of chemical sinks for NOx species (Celarier $e t$ al., 2008).

The temporal changes in $\mathrm{O}_{3}$ concentrations, driven partly by changing seasons, have implications on the climate, vegetation and lives on earth. Photochemical reaction of pollutants such as $\mathrm{NO}_{\mathrm{x}}$ results in ground level $\mathrm{O}_{3}$. At levels exceeding $100 \mu \mathrm{g} / \mathrm{m}^{3}, \mathrm{O}_{3}$ in the air can cause among other human health effects, breathing problems (WHO, 2006). It is an important gas because of its absorption of the biologically harmful ultraviolet radiation, thereby protecting live on the earth's surface.

Both stratospheric and tropospheric $\mathrm{O}_{3}$ is largely produced naturally through photochemical and chemical reactions (Ogunjobi et al., 2007). However, the human-induced depletion of $\mathrm{O}_{3}$ by Chlorofluorocarbons (CFCs) is more of a concern because the process is rapid. The distribution of $\mathrm{O}_{3}$ is influenced by seasonal transport from one location to the other as a result of seasonal circulations in the atmosphere. It implies, therefore that $\mathrm{O}_{3}$ concentration will vary depending on the season of the year. For example, seasonal $\mathrm{O}_{3}$ variation showing springtime maximum over South Africa have been revealed using ground-based observations (Diab et al., 2004) emphasizing the influence of synoptic weather systems. Over equatorial Africa, the lower troposphere exhibits layers of enhanced $\mathrm{O}_{3}$ during the biomass burning season in each hemisphere (Sauvage et al., 2004). The exchange of $\mathrm{O}_{3}$ between the stratosphere and troposphere also take place on a seasonal scale (Diab et al., 2004).

Whereas the station observations of air pollutants concentrations in the past have often been limited in spatial coverage, the more recently available satellite measurements now provide a means to link local production of pollution with regional and global scale transport (Edwards et al., 2003). In Africa as a whole, only few studies have illustrated the variability of criteria pollutants due to inadequate ground-based measurements. Moreover, such studies are centered on and around South Africa. Thus, there is sparse documentation on this important research area. Since the South and East Africa where Nairobi is situated have climatic disparity, a distinct difference in their selected air pollutant climatology is expected. This study, using satellite data aims at bridging this important gap.

The aim of this study to analyse in detail, the temporal variation of total column $\mathrm{NO}_{2}$ and $\mathrm{O}_{3}$ on daily, monthly and 
interannual annual basis over the Nairobi County for the time period of 2009-2013. It relates the temporal evolution of total column $\mathrm{NO}_{2}$ and $\mathrm{O}_{3}$ to the climatology of the study area with an intention of establishing the role of the area's varying seasons on their concentrations.

\section{Study Area}

Nairobi is situated at $1.17^{\circ} \mathrm{S}, 36.49^{\circ} \mathrm{E}$ in the highlands of the southern part of the country. It is Kenyan's capital city and the country's major economic and administrative centre and is one of the largest and fastest growing cities in Africa. The city has the highest urban population in East Africa, estimated at 3.14 million (KNBS, 2009) living within $684 \mathrm{~km}^{2}$. At roughly $1660 \mathrm{~m}$ above sea level, Nairobi has a fairly moderate climate. The two main seasons are; the long wet season between March and May and the dry season between December and February of the following year. Figure 1 is a map of the study area; showing Nairobi County.

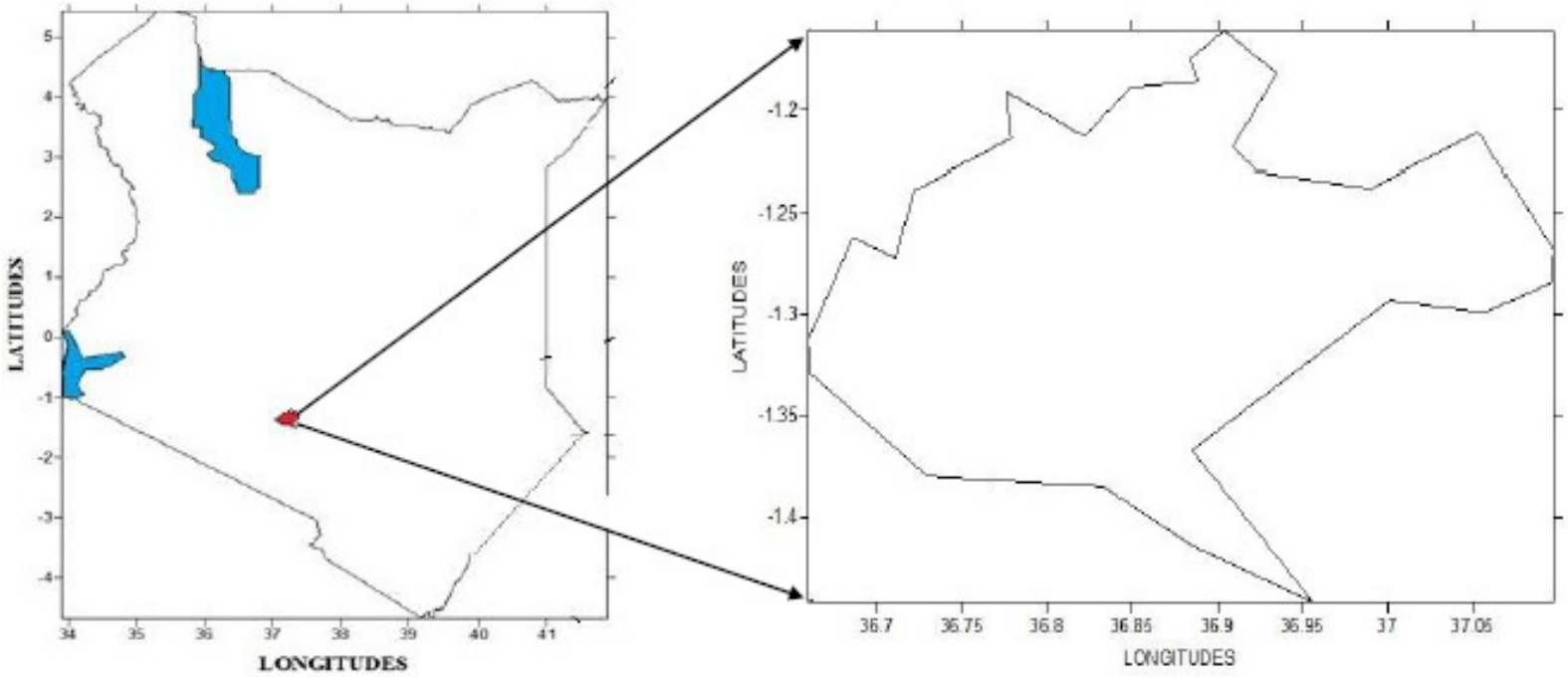

Figure 2: Map of Kenya (right) showing the location of the study area; Nairobi County (left)

\section{Methodology}

\section{Data Collection}

The data used in this study are daily total column amount nitrogen dioxide (OMNO2e version 3) and ozone (OMTO3e version 3) based on TOMS algorithm from 1 January 2009 to 31 December 2013 over Nairobi. These were obtained using Giovanni interface for visualization and analysis of the Earth Observing System (EOS) Aura Ozone Monitoring Instrument (OMI) version 3 daily level 3 global $0.25^{\circ}$ gridded data. OMI is a spaceborne spectroradiometer that flies onboard the National Aeronautics and Space Administration's (NASA) EOS Aura satellite launched in July 2004. OMI employs the concept of measuring the complete spectrum in the ultraviolet/visible/near-infrared wavelength range with a high spectral resolution. Even though TOMS has the advantage that it has a fairly small ground-pixel size $(50 \mathrm{~km}$ by $50 \mathrm{~km}$ ) in combination with a daily global coverage, OMI combines the advantage of Global Ozone Monitoring Experiment (GOME) and Scanning Imaging Absorption Spectrometer for Atmospheric Chartography (SCIAMACHY) with the advantage of TOMS, measuring the complete spectrum in the ultraviolet/visible wavelength range with a very high spatial resolution $(13 \mathrm{~km}$ by $24 \mathrm{~km})$ and daily global coverage. This is possible by using a two-dimensional (2-D) charge-coupled 
device (GCD) array detector (Celarier et al., 2008).

The OMI's dataset has been extensively validated, and the errors are reasonably well understood (Celarier et al., 2008). OMI total column $\mathrm{NO}_{2}$ appears to have a negative bias with respect to measurements from ground-based and DS-DOAS (Celarier et al., 2008), GOME (Martin et $a l ., 2002)$ and SCIAMACHY (Schneider and van der, 2012). Even with the significant apparent bias, a good correlation is reported, generally $>0.6$ (Celarier $e t$ al., 2008). Again, $\mathrm{OMI}^{\prime} \mathrm{O}_{3}$ data have been found to compare reasonably well with ground-based measurements and other satellite platforms; a globally averaged agreement of better than $1 \%$ for OMITOMS data and better than $2 \%$ for OMIDOAS data with the ground-based observations.

The data resolution is $0.25^{\circ}$ latitude by $0.25^{\circ}$ longitude. The readings were extracted from single cell within which the surface station lies with the aid of a simple R-NETCDF program. The data are measured in Dobson Units (DU).

\section{Results and Discussion Daily Variation}

The cyclic nature of both daily $\mathrm{NO}_{2}$ and $\mathrm{O}_{3}$ concentration depicts a seasonal phase, exhibiting a wavelength of about 420 Julian days (starting from $1^{\text {st }}$ January, 2009). This implies that shorter than one cycle is complete in a year as shown in Figure 2. The cycles start with a minimum during the period of dry season (December-January), and gradually assume a maximum during the period of wet season (March-May) and cold season (June-August). Minimum and maximum $\mathrm{NO}_{2}$ and $\mathrm{O}_{3}$ concentrations over Nairobi are found to occur principally in January and September, respectively. However in Nairobi the period of warm and dry season occurs in December and extends to February of the following year, period of cold and dry occur in June-August while periods of wet and cold seasons occur in March-May (long rains) and OctoberDecember (short rains), respectively. This implies a one-month lag between the onset of a season and minimum or maximum $\mathrm{NO}_{2}$ and $\mathrm{O}_{3}$ concentration, correspondingly. For the total number of years considered, $\mathrm{NO}_{2}$ maximum and minimum concentration over Nairobi was 6.9 DU and 1.8 DU, respectively producing an average range of $4.8 \mathrm{DU}$, which is about $145.45 \%$ of the mean value (3.3 DU). On the other hand $\mathrm{O}_{3}$ maximum and minimum level was 289 DU and 227 DU, respectively producing an average range of 62 DU, only about $24.16 \%$ of the mean value (256 \pm 6.9$)$. Comparable results $(254.35 \pm 8.25 \mathrm{DU})$ have been reported by Ogunjobi et al. (2007). It was noted that at no day during the entire study period over Nairobi was ozone concentration below 220 DU minimum mark otherwise known as ozone hole, recorded. Odhiambo et al. (2010) have reported that even though $\mathrm{O}_{3}$ and $\mathrm{NO}_{2}$ are within the $\mathrm{WHO}$ guidelines over Nairobi, higher levels of $\mathrm{NO}_{2}$ are detected during the morning and evening traffic peak hours. This clearly shows that motor vehicles are the most probable source of these gaseous pollutants within the city centre. 

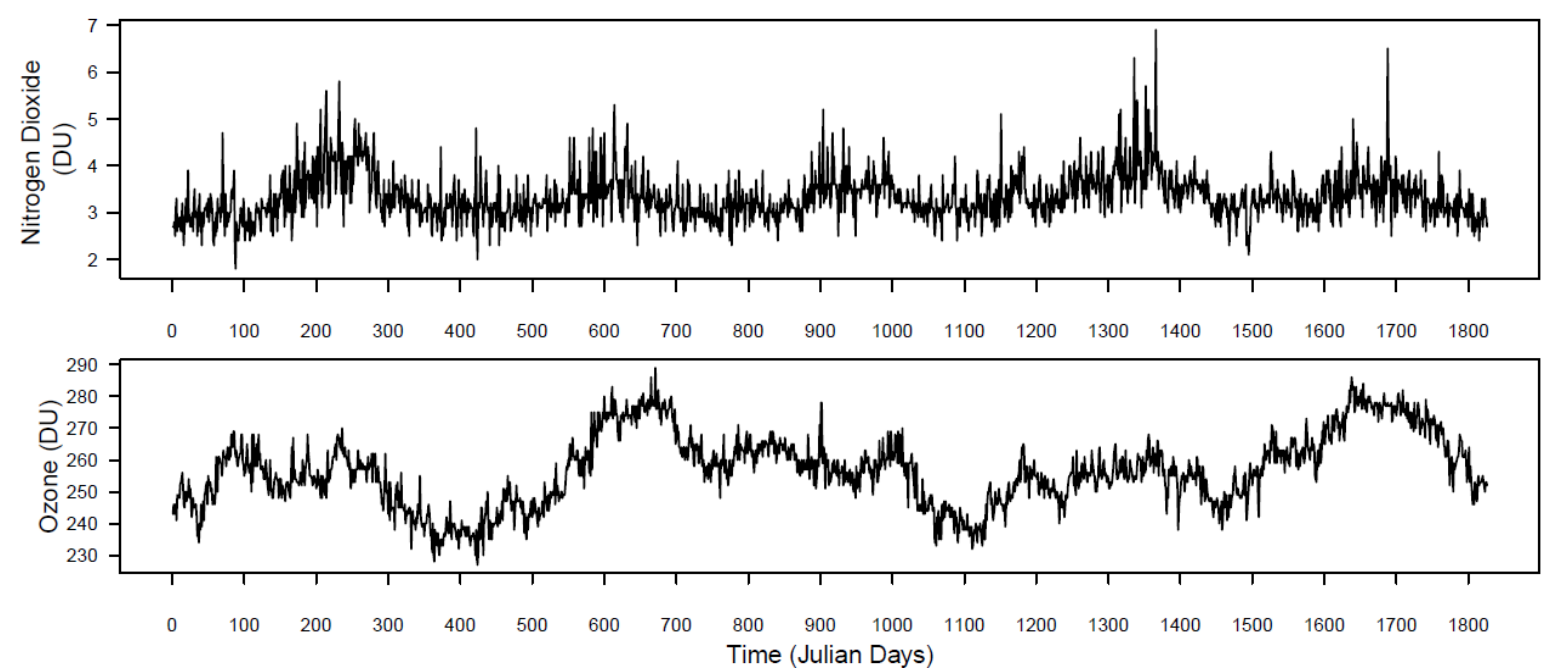

Figure 3: Cyclic nature of both daily total column $\mathrm{NO}_{2}$ and $\mathrm{O}_{3}$ concentration over Nairobi

\section{Monthly Variation}

The shapes of mean monthly evolution of total column $\mathrm{NO}_{2}$ and $\mathrm{O}_{3}$ for the fiveyear averaged data are as shown in figure 3. Both $\mathrm{NO}_{2}$ and $\mathrm{O}_{3}$ concentrations generally grow from January and reach peaks in September which then diminish thereafter to December. Precisely, Ozone depicts a slight peak during the long rains in MarchMay and a major peak in August-October just before the commencement of the short rains. Bundi (2004) also showed that tropospheric $\mathrm{O}_{3}$ depicts a maximum during this period over Nairobi. Minimum values are realized in December-February. Similar seasonal patterns have been observed by Ayoma et al. (2002) with total $\mathrm{O}_{3}$ measurements by Dobson instrument. Thomas et al. (2003), attributes enhanced total column $\mathrm{O}_{3}$ and unusually high levels of $\mathrm{NO}_{2}$ during such periods to severe thunderstorms and extreme rainfall and intrusion of stratospheric air. According to Thomas et al. (2003) much of the total atmospheric content of $\mathrm{NO}_{2}$ is found in the troposphere, due to lightning activity, advection and vertical transport in the thunderstorms from the planetary boundary layer (PBL) to atmospheric levels above clouds. Diab et al. (2004) have suggested that similar seasonal springtime tropospheric ozone maximum over South Africa is strongly influenced by nonseasonally fluctuating sources such as urban-industrial emissions because of its proximity to major metropolitan and industrial areas. Seasonal enhancements from biomass burning occur over northern Africa during December-February and over central Africa during June-October (Martin et al., 2003).

Despite the similarity in the shape depicted by monthly evolution of nitrogen dioxide and ozone over Nairobi, the disparity in (spike) peakedness of the evolution, particularly the dip is however noted. 

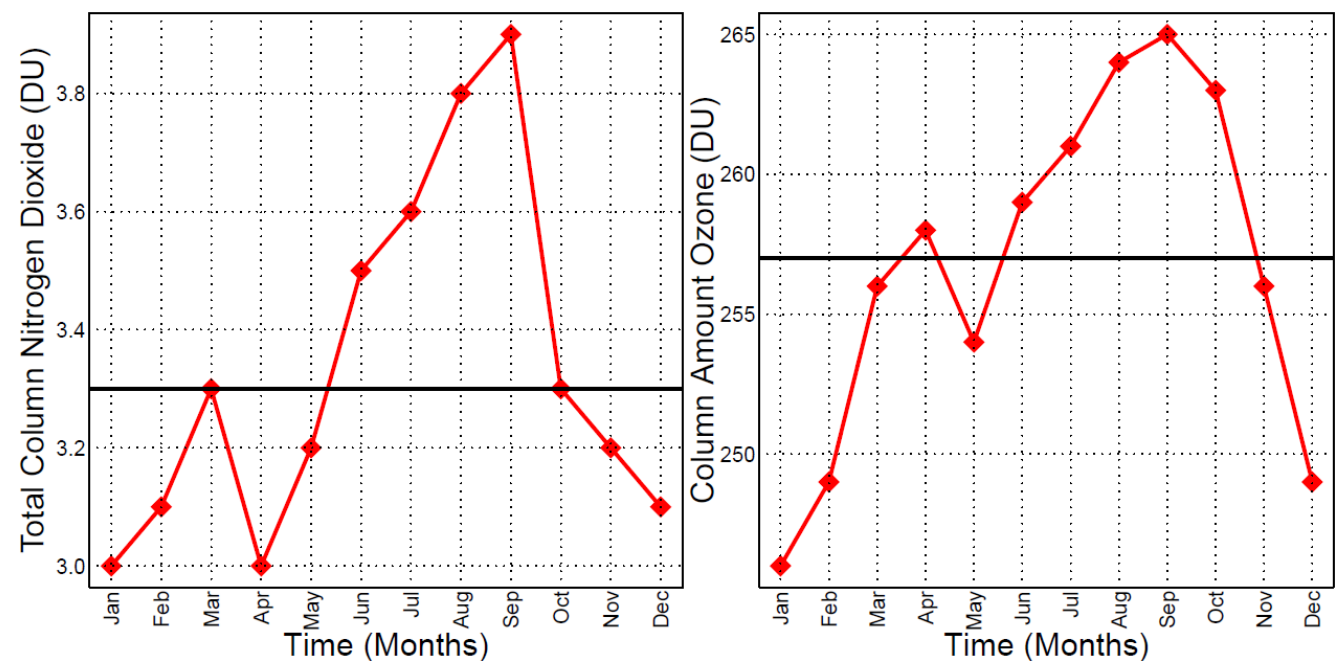

Figure 4: Mean monthly evolution of total column $\mathrm{NO}_{2}$ and $\mathrm{O}_{3}$ for the five-year averaged data

The persistence in both the monthly $\mathrm{NO}_{2}$ and $\mathrm{O}_{3}$ trends was examined by calculating their autocorrelation functions (ACFs). Sample autocorrelation coefficients measure the correlation between observations at different times (Box and Jenkins, 1976). The set of such autocorrelation coefficients arranged as a function of separation in time is the ACF. Persistence determines the retention memory of the factors responsible for variations in a system, in this case monthly $\mathrm{NO}_{2}$ and $\mathrm{O}_{3}$ variation. Figure 4 shows $\mathrm{ACF}$ for Nairobi with a time lag of 1 to 12 months. Although in general, one should test for autocorrelation at lags one to lag $\mathrm{n} / 4$, where $\mathrm{n}$ is the total number of observations in the analysis, estimates at longer lags have been shown to be statistically unreliable (Box and Jenkins, 1976). In some cases, the effect of autocorrelation at smaller lags will influence the estimate of autocorrelation at longer lags resulting in an apparent correlation, even though no direct correlation exists. Although the Partial Autocorrelation Function (PACF) removes the effect of shorter lag autocorrelation from the correlation estimate at longer lags, the estimate is only valid to one decimal place. ACF and PACF each vary between plus and minus one, with values closer to plus or minus one indicating strong correlation. Negative ACF means that a positive return for one observation increases the probability of having a negative return for another observation, depending on the lag and vice-versa. The confidence limits are provided to show when ACF or PACF appears to be significantly different from zero. In other words, lags having values outside these limits (shown as blue dotted lines) should be considered to have significant correlation.

The systems of both $\mathrm{NO}_{2}$ and $\mathrm{O}_{3}$ autocorrelations became decoupled after a one-month lag indicated by non-persistence in the autocorrelations as the lag increases. This is attributed to the short memory of pollutant controlling factors. A remarkable feature noticed in the ACFs is the transformation of sign from positive to negative at lag 3 . This may be due to the 3month contrasting wind systems over Nairobi. $\mathrm{NO}_{2}$ ACF achieved stability between lag 5 and 6 and then changed sign for the second time from negative to positive at lag 10. Ozone ACF achieved stability between lag 8 and 9 and then 
changed sign for the second time from negative to positive at lag 11 . This stabilization may be attributed to active weather systems during those 2-3 months. Active weather ensures strong mixing and

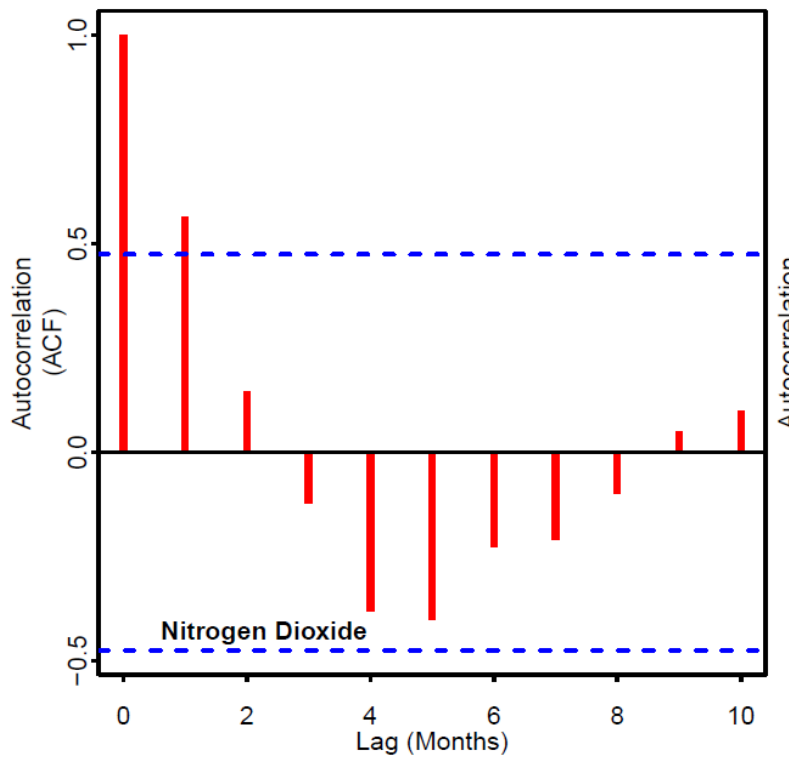

Figure 5: Autocorrelation Functions (ACF) for Nairobi with a time lag of 1 to 12 months

The relationship between monthly $\mathrm{NO}_{2}$ and $\mathrm{O}_{3}$ time series was described by calculating the cross correlation functions (CCFs). Generally, in the relationship between two time series $\left(y_{t}\right.$ and $\left.x_{t}\right)$, the series $y_{t}$ may be related to past lags of the $x$ series. In such a case, the sample cross correlation function (CCF) is helpful for identifying lags of the $x$-variable $\left(\mathrm{NO}_{2}\right)$ that might be useful predictors of $y_{t}\left(\mathrm{O}_{3}\right)$. In R, the sample $C C F$ is defined as the set of sample correlations between $x_{t+k}$ and $y_{t}$ for $k=0, \pm 1, \pm 2, \pm 3$, and so on. A negative value for $k$ is a correlation between the $x$-variable at a time before $t$ and the $y$-variable at time $t$, and $x$ is said to be leading $y$. When $\mathrm{h}$ is positive $x$ is said to be lagging $y$.

Although in some problems, the goal may be to identify which variable is leading and which is lagging, in this case the $x$ variable $\left(\mathrm{NO}_{2}\right)$ was examined to be leading variable of the $y$-variable (Ozone). vigorous transport of pollutants. During periods of active weather the incursion/exchange of ozone due to interplay of stratospheric and tropospheric elements is enhanced.

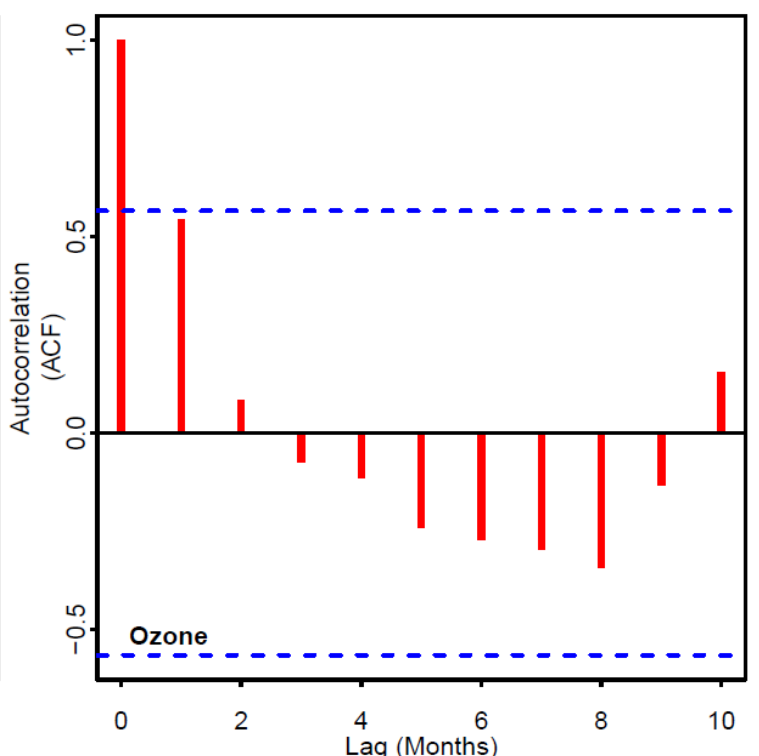




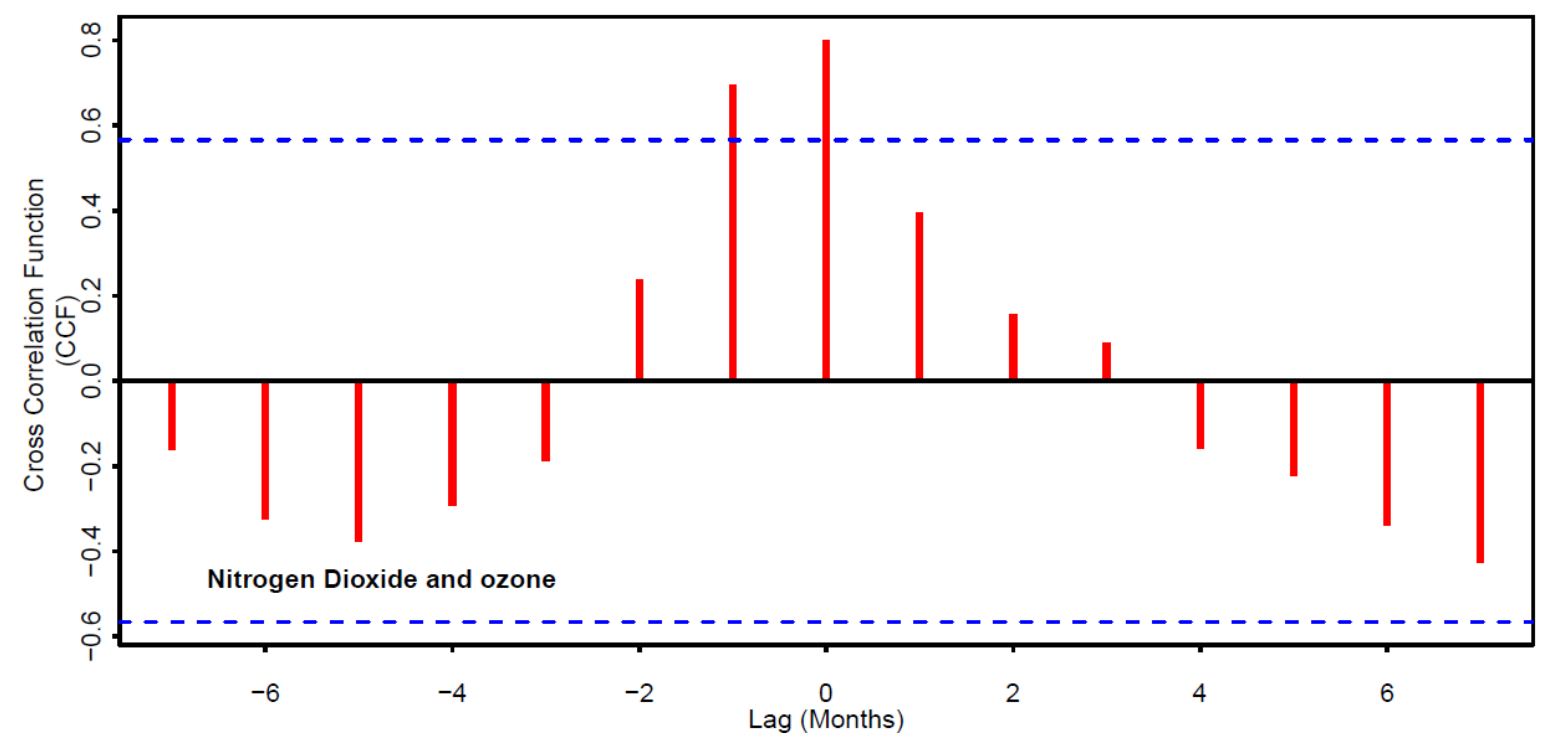

Figure 6: Crosscorrelation Functions (CCF) for Nairobi with a time lag of 1 to 7 months

\section{Interannual Variation}

Figure 5 shows interannual variations of average $\mathrm{NO}_{2}$ and $\mathrm{O}_{3}$ concentrations for five years. The interannual variation presents an interesting feature in which both $\mathrm{NO}_{2}$ and $\mathrm{O}_{3}$ concentrations oscillate biennially. $\mathrm{NO}_{2}$ dipped in 2010 and peaked in 2012 before dipping again. $\mathrm{O}_{3}$ increased in 2011 but plunged in 2012 and increased again in 2013. Several studies have termed the observed interannual oscillation of $\mathrm{O}_{3}$ as a footprint of quasi-biennial oscillation (QBO) that occurs every two years, and that dominates the ozone variability in the tropics (Chehade et al., 2014; Logan et al., 2003). QBO is a global upper level atmospheric circulation. Its activity has marked effects on wind regimes that control rainfall. Since these wind systems are a factor in ozone variations, QBO activity therefore appears to aid $\mathrm{O}_{3}$ accumulation because the effect of the circulation that trickles down from upper atmosphere could transport $\mathrm{O}_{3}$ to the stratosphere and troposphere. Tropospheric $\mathrm{O}_{3}$ anomalies associated with the QBO of about $10-20 \%$ that of typical tropospheric $\mathrm{O}_{3}$ values (Lee et al., 2010). $\mathrm{O}_{3}$ accumulation due to the QBO effects, comparing years 2009 and 2010 only, could be as high as $2.24 \%$ over Nairobi (Lee et al., 2010). Effects of ENSO on $\mathrm{O}_{3}$ have also been observed. Negative tropospheric $\mathrm{O}_{3}$ anomalies have been reported over Nairobi consistent with anomalous upwelling expected during ENSO events (Lee et al., 2010). According to Chehade et al. (2014), the signature of the 11-year solar cycle also covers all latitudes and contributes about $10 \mathrm{DU}$ of $\mathrm{O}_{3}$ from solar maximum to solar minimum. 

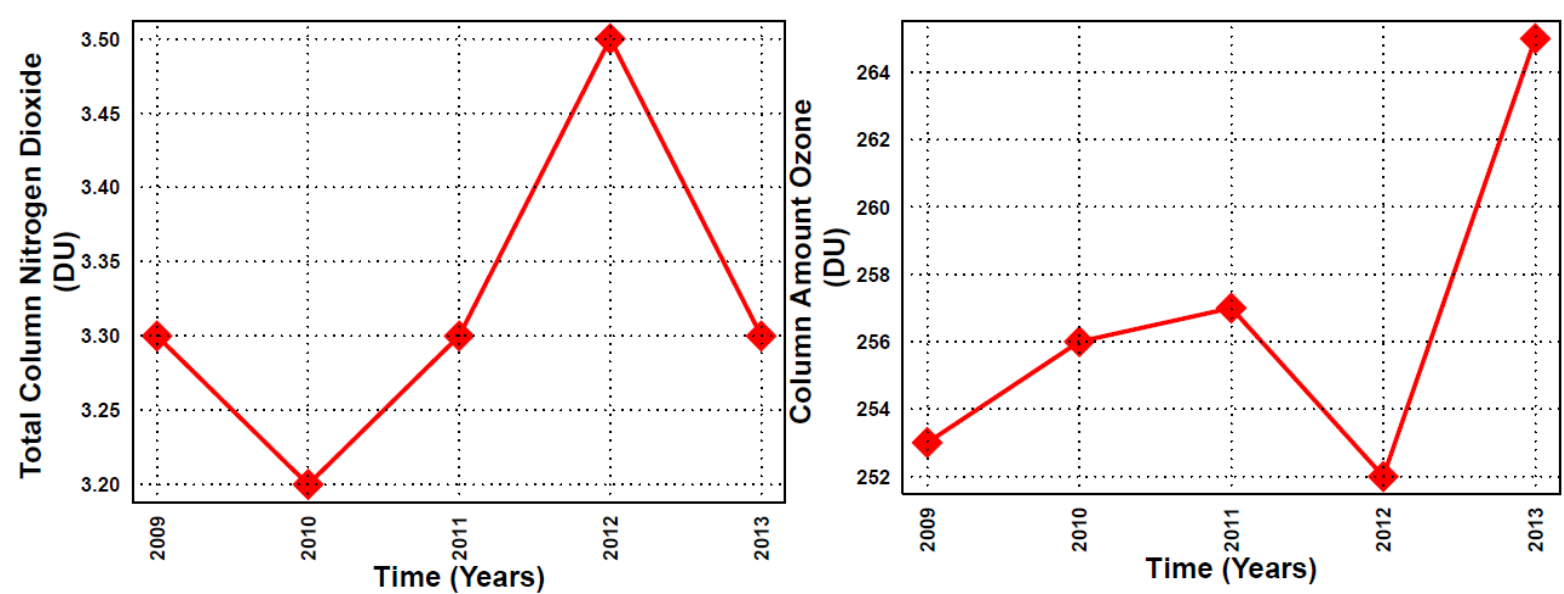

Figure 7: Interannual variations of average $\mathrm{NO} 2$ and $\mathrm{O} 3$ concentrations for five years

The analysis of the year to year variation revealed increasing trends of both $\mathrm{NO}_{2}$ and $\mathrm{O}_{3}$ concentrations over Nairobi. Average increasing rates of $0.01 \mathrm{DU} /$ year ( $0.27 \%$ per year compared to mean value) and 1.19 DU/year $(0.46 \%$ per year compared to mean value) for $\mathrm{NO}_{2}$ and $\mathrm{O}_{3}$ concentrations, respectively. Similarly increasing $\mathrm{O}_{3}$ trends $(0.89 \mathrm{DU} / \mathrm{yr}$ or $0.35 \%$ year $^{-1}$ ) have been observed over Nairobi by Ogunjobi et al. (2007). The increasing rate of ozone could be aggravated in the face of increasing anthropogenic activities. An increase $(\sim 10 \mathrm{ppbv})$ in surface and lower tropospheric ozone in all seasons except in summer is attributed to an increase in urban-industrial emissions in response to the corresponding population increase (Diab et al., 2004). An increase in the domestic use of biofuels for heating in poor urban settlements is expected to account for the contrasts between summer and other seasons.

\section{Conclusions}

The temporal evolution of $\mathrm{NO}_{2}$ and $\mathrm{O}_{3}$ over Nairobi has been analysed. The role of rainfall producing mechanism has been stressed. $\mathrm{NO}_{2}$ and $\mathrm{O}_{3}$ distribution is mostly controlled by thunderstorms and extreme rainfall and intrusion of stratospheric air. This is such that their accumulation follows synchronously the migration of wind systems. The relationship between monthly $\mathrm{NO}_{2}$ and $\mathrm{O}_{3}$ is such that, above average concentration of $\mathrm{NO} 2$ is likely to lead to above average levels of $\mathrm{O} 3$ during the same month $(\mathrm{r}=0.79)$ and below average levels about 5 months later $(\mathrm{r}=0.39)$. As reported by Chehade et al. (2014), oscillating biennial feature exhibited by $\mathrm{NO}_{2}$ and $\mathrm{O}_{3}$ interannual trend is considered as the footprints of the upper level atmospheric circulation referred to as quasi biennial oscillation (QBO). This circulation acts to increase the exchange of ozone between the stratosphere and the troposphere.

It has also been shown that $\mathrm{NO}_{2}$ and $\mathrm{O}_{3}$ are increasing at annual average rates of about $0.27 \%$ and $0.46 \%$ per year compared to mean values, respectively. The increasing rate of ozone could be aggravated in the face of increasing urbanindustrial emissions in response to the corresponding population increase (Diab et al., 2004). Daily variation of both $\mathrm{NO}_{2}$ and $\mathrm{O}_{3}$ depicts stagnating trends over the entire period of study. This difference is attributed to the fact that, whereas daily $\mathrm{NO}_{2}$ and $\mathrm{O}_{3}$ are influenced by mechanisms that control the gradual transition of dry period to wet period within the course of a year, interannual variability is driven by the differences in each year's general weather conditions. 


\section{Acknowledgements}

The authors express a profound gratitude to OMI group at NASA Goddard Space Flight Centre for making the OMI data used for this work available on their web site. The authors would also like to thank the Department of Meteorology, University of Nairobi for providing support during the study.

\section{References}

Box, G.E., and Jenkins, G.M. (1976). Time series analysis: forecasting and control, revised ed. Holden-Day.

Bundi, P.M. (2004). Spatial and temporal distribution of tropospheric ozone over Southern Africa. (Unpublished doctoral thesis). Faculty of Science, University of the Witwatersrand, South Africa.

Cede, A., Herman, J., Richter, A., Krotkov, N. and Burrows, J. (2006).

Measurements of nitrogen dioxide total column amounts using a Brewer double spectrophotometer in direct Sun mode. Journal of Geophysical Research: Atmospheres (1984-2012), 111(D5).

Celarier, E. A., Brinksma, E. J., Gleason, J. F., Veefkind, J. P., Cede, A., Herman, J. R., \& Levelt, P. F. (2008). Validation of Ozone Monitoring Instrument nitrogen dioxide columns. Journal of Geophysical Research: Atmospheres (19842012), 113(D15).

Chehade, W., Weber, M. and Burrows, J.P. (2014). Total ozone trends and variability during 1979-2012 from merged data sets of various satellites. Atmospheric Chemistry and Physics, 14(13): 7059-7074.

David, L.M. and Nair, P.R. (2011). Diurnal and seasonal variability of surface ozone and $\mathrm{NO}_{\mathrm{x}}$ at a tropical coastal site: Association with mesoscale and synoptic meteorological conditions. Journal of Geophysical Research: Atmospheres (1984-2012), 116(D10).
Diab, R.D., Thompson, A.M., Mari, K., Ramsay, L., and Coetzee, G.J.R. (2004). Tropospheric ozone climatology over Irene, South Africa, from 1990 to 1994 and 1998 to 2002. Journal of Geophysical Research: Atmospheres (19842012), 109(D20).

Edwards, D.P., Lamarque, J.F., Attié, J.L., Emmons, L.K., Richter, A., Cammas, J.P., and Burrows, J.P. (2003). Tropospheric ozone over the tropical Atlantic: A satellite perspective. Journal of Geophysical Research: Atmospheres (19842012), 108(D8).

Finlayson-Pitts, B.J., and Pitts, J. (2000). Chemistry of the Upper and

Lower Atmosphere: Theory, Experiments, and Applications, New York: Elsevier.

Gritsai, Z.I., Evtushevsky, A.M., Leonov, N.A. and Milinevsky, G.P. (2000). Comparison of ground based and TOMS-EP total ozone data for antarctica and Northern Midlatitude Stations (1996-1999). Physics and Chemistry of the Earth, Part B: Hydrology, Oceans and Atmosphere, 25(5): 459-461.

Herman, J. R. (2010). Use of an improved radiation amplification factor to estimate the effect of total ozone changes on action spectrum weighted irradiances and an instrument response function. Journal of Geophysical Research: Atmospheres (1984-2012), 115(D23)

KNBS (Kenya National Bureau of Statistics), (2010). Kenya 2009 Population and Housing Census Highlights. (Ministry of Planning Publication). Nairobi: Kenya, Government Printer.

Lee, S., Shelow, D.M., Thompson, A.M. and Miller, S.K. (2010). QBO and ENSO variability in temperature and ozone from SHADOZ, 19982005. Journal of Geophysical Research: Atmospheres (19842012), 115(D18). 
Liley, J.B., Johnston, P.V., McKenzie, R.L., Thomas, A.J. and Boyd, I.S. (2000). Stratospheric $\mathrm{NO}_{2}$ variations from a long time series at Lauder, New Zealand. Journal of Geophysical Research: Atmospheres (19842012), 105(D9), 11633-11640.

Logan, J.A., Jones, D.B.A., Megretskaia, I.A., Oltmans, S.J., Johnson, B.J., Vömel, H. and Schmidlin, F.J. (2003). Quasibiennial oscillation in tropical ozone as revealed by ozonesonde and satellite data. Journal of Geophysical Research: Atmospheres (1984-2012), 108(D8).

Martin, R.V., Chance, K., Jacob, D.J., Kurosu, T.P., Spurr, R. J., Bucsela, E. and Koelemeijer, R. (2002). An improved retrieval of tropospheric nitrogen dioxide from GOME. Journal of Geophysical Research: Atmospheres (1984-2012), 107(D20), ACH-9.

Martin, R.V., Jacob, D.J., Chance, K., Kurosu, T.P., Palmer, P.I. and Evans, M. J. (2003). Global inventory of nitrogen oxide emissions constrained by space-based observations of $\mathrm{NO}_{2}$ columns. Journal of Geophysical Research: Atmospheres (1984-2012), 108(D17).

Odhiambo, G.O., Kinyua, A.M., Gatebe, C. K. and Awange, J. (2010). Motor Vehicles Air Pollution in Nairobi, Kenya. Research Journal of Environmental and Earth Sciences, 2(4): 178-187.

Ogunjobi, K.O., Ajayi, V.O., and Balogun, I.A. (2007). Long Term Trend Analysis of Tropospheric Total Column Ozone in Africa. Research Journal of Applied Science, 2, 280-284.

Ordónez, C., Richter, A., Steinbacher, M., Zellweger, C., Nüß, H., Burrows, J.P. and Prévôt, A.S.H. (2006). Comparison of 7 years of satellite-borne and ground-based tropospheric $\mathrm{NO}_{2}$ measurements around
Milan, Italy. Journal of Geophysical Research: Atmospheres (1984-2012), 111(D5).

Sauvage, B., Thouret, V., Cammas, J. P., Gheusi, F., Athier, G. and Nédélec, P. (2004). Tropospheric ozone over Equatorial Africa: regional aspects from the MOZAIC data. Atmospheric Chemistry and Physics Discussions, 4(3): 3285-3332.

Schneider, P. and van der, R.J.A. (2012). A global single-sensor analysis of 2002-2011 tropospheric nitrogen

dioxide trends observed from space. Journal of Geophysical Research: Atmospheres (19842012), 117(D16).

Seinfeld, J.H. and Pandis, S.N. (2012). Atmospheric chemistry and physics: from air pollution to climate change. John Wiley \& Sons, pp. 1974.

Solomon, S., Qin, D., Manning, M., Chen, Z., Marquis, M., Averyt, K.B. and Miller, H.L. (2007). Climate Change 2007: The Physical Science Basis. Contribution of Working Group I to the Fourth Assessment Report of the Intergovernmental Panel on Climate Change, (Vol. 4). Cambridge University Press.

Thomas, W., Baier, F., Erbertseder, T. and Kästner, M. (2003). Analysis of the Algerian severe weather event in November 2001 and its impact on ozone and nitrogen dioxide distributions. Tellus B, 55(5): 9931006.

WHO (World Health Organisation), (2006). WHO Air Quality Guidelines, World Health Organisation (WHO) Regional Office for Europe, Copenhagen, Denmark, 2006, Global Update 2005. http://www.euro.who.int/Document/E9 0038.pdf 